\title{
「満洲国」の中のスパイ/スパイ戦
}

——スパイ小説「間諜茉莉」論

Zhanyi WANG(王占一: PhD student, Nagoya University Graduate School of Letters)

四angzhanyi123@126.com

(日本) 名古屋大学大学院人文学研究科博士後期課程。近現代日本文学、「満洲」文学。主著に「探 偵創作加国策宣伝へ:大庭武年と「満州国」戯曲」(『名古屋大学国語国文学』第111号, 2018)、「戦前 戦時における中国民謡の機能:雑誌『満蒙』を中心に(『名古屋大学人文学フォーラム』第1号、2018)、 「柴田天馬と『聊斎志異』:天馬訳『聊斎志異』のルビと訳注に注目して」『跨境:日本語文学研究』第7号, 2018)など。

\section{Spying and Espionage in Manchukuo: An Analysis of the Espionage Novel Spy Molly}

After the establishment of Manchukuo in 1932, Japanese writers living there produced a range of novels set in Manchukuo, although Manchu magazine focused mainly on publishing short stories. Though many novels feature the kind of propaganda that accompanied the establishment of Manchukuo, there are also many works which reflect the real situation of that period, including espionage novels. At the time when Manchukuo had just been established, the level of espionage among the countries in the region was intense, and so this was a hugely significant issue. Meanwhile, spying and espionage had become a literary subject, and espionage novels set in Manchukuo emerged as a popular form. The Japanese writers there created such novels with plots that are deeply connected to the social environment. An example is Spy Molly, written by Konetoh Juro, which was published in the $164^{\text {th }}$ issue of Manchu. In this paper, based on an overview of the espionage which was current among countries in the region and the resulting production of espionage novels, specific features of the espionage novels of Manchukuo are discussed, using Spy Molly as a prime example.

Keywords Manchukuo(満洲国), Spy(スパイ), Espionage Novel(スパイ小説), $\operatorname{Spy} \operatorname{Molly}($ 「間諜茉莉」) 


\section{1 はじめに}

「満洲国」においては、様々な勢力が咙扈し各国間で展開されたスパイ戦も激しく なった。スパイの話は大衆の間で語られるだけでなく、多くの文学者によっても描か れていた。そのようにして「満洲国」のスパイに関する小説が現れたのである。本論で はこのような小説をスパイ小説と称する。スパイ小説は「満洲国」を舞台にし、角逐し合 う各勢力のスパイ戦を描写対象にしている一方で、男女主人公の悲劇的な恋愛物語も描 かれている。

雑誌『満蒙』の第164号(1933年12月)に掲載された近東綺十郎の小説「間諜莱莉」がその 一例として挙げられる。「茉莉」という名称の使用というと、1929年に刊行された安西冬 衛の詩集『軍艦茉莉』を連想させる。詩集『軍艦茉莉』は大連を背景にして植民地主義の狂 想を示している。当時大連に在住した近東綺十郎が小説を創作する際に「茉莉」の名称を 援用するのは詩集『軍艦茉莉』から影響を受けたかと思われる。「間諜莱莉」においては、 主人公の父親が日本人であり母親が満人であるとの設定が、非常に興味深い。また、作 者が物語の展開において、単なる恋愛物語を記述しただけではなく、当時の時局と深く 関連させ、主人公の運命と時局との関係を追求していることが重要である。「間諜茉莉」

こそ、もっともこの時代の『満蒙』を代表するスパイ小説だと言えるだろう。

本論ではまず、「満洲国」成立後の「満洲」で展開された各勢力のスパイ戦を概説し、そ れを踏まえてスパイ小説の創作と時局との間の緊密な関係性を明らかにする。その上 で、「間諜茉莉」を研究テクストとして「満洲国」時代に在満日本人が書いたスパイ小説の 特徵を分析する。さらに、恋愛物語の背後に隠されたスパイ戦に対する内部的な批判を 検討する。

\section{2「満洲国」、スパイ戦、スパイ小説}

1931年9月18日、中国東北に駐屯した日本の関東軍が、南満洲鉄道の線路を爆破した 事件(柳条湖事件)に端を発し、中国東北軍の北大営を砲撃して潘陽に侵攻し、中外を驚 かせた「満洲事変」を起こした。翌日、日本軍は潘陽を占拠し、数日で長春、吉林などの 地を占領した。1932年2月には東北全土が陥落した。1933年5月31日の塘活協定成立に至 るまで日本と中国との間の武力紛争が続いていたのである。

「満洲事変」とは日本帝国主義が中国を武力で征服しようとした戦争の始まりであると 考えられている。1932年3月9日、日本軍の「扶持」によって最後の皇帝・溥儀は、長春に 傀儡政権の「満洲国」を建てた。日本は同年の9月15日、関東軍司令官兼駐満洲全権大使で ある武藤信義と「満洲国」首相である鄭孝旻が長春で「日満議定書」を締結したことで、「満 洲国」を公式に認めた。「満洲国」の成立によって中国東北の社会環境が変わり、「満洲」に 
おける各勢力の角逐も白熱した。そのため「満洲国」ではスパイ戦を巡って諜報活動が頻 繁に行わ机ていた。森島守人は著作の『陰謀・暗殺・軍刀一外交官の回想』(1950年出版)に おいて、当時の中・日・欧米の間の関係について、次のように述べている。

中国の欧米依存の傾向や中国における第三国の権益から見て、中国に莫大な権益 を有するイギリスやアメリカとの間にも話合をすることが必要だ。すなわち中日関 係と日、英米関係とを相関的に取りあつかうことが必要だということであった。1

森島の述べたように、「満洲国」においては各国の間の関係が絡み合い、その社会背 景は非常に複雑かつ混乱した状態にあった。このような社会環境が諜報活動の温床で あったといえよう。また、諜報活動の激化によって満洲国」あるいは日本の防諜活動も 進歩していたのである。ここで日本のスパイ史を遡ってみると、日露戦争中、日本はす でにスパイ戦を開始していた。中園英助は『スパイの世界』において「一九四年から五 年にかけての日露戦争は、まさに二十世紀をスパイの世紀へと開幕させたのである」と 指摘している。日露戦争の後に日本が中国東北に設立した満鉄は、事実上、日本の情報 機関であった。中園は「満鉄」について次のように指摘している。

ユニオン・ジャックの翻るところに太陽は沈まぬと豪語し、七つの海に覇をとな えたイギリスが、情報機関によって植民地を巧みに練り上げていったことは良く知 られている。たとえば、インドにおける東インド会社がその一つの母体で、中国東 北の旧満洲における満鉄(南満洲鉄道株式会社)は東インド会社を模做したものであ り、満鉄調査部といえば極東における最大最強の情報機関であった。今日でいう フィールド・ワークとシンク・タンクとを兼权たこの超情報機関は、鉄道による点 と線が満洲国の面へと拡大してゆく、巨大な陰の頭脳となったのである 3 。

「満洲国」が成立した後、日本は、当時の複雑な国際環境に対応すべく最も厳密な情報 網を配置した。まず、参謀本部内に特種情報班を編成し1934年に関東軍参謀部第二課に 大久保俊次郎大佐を班長とする関東軍特種情報機関を設立した。この機関について、イ ンテリジェンス研究者の小谷賢は「1941年関東軍司令部直属の関東軍特種情報部、1944年 には関東軍通信情報(通称「満188部隊」)なり、最盛期には1090名もの人員を抱えていた」4 と指摘している。彼は、戦争中の情報機関による諜報活動を「人的情報(ヒューミント)」 と言い、次のように述べている。

人的情報というとスパイのようなものが連想される。基本的に情報収集は海外の

\footnotetext{
1 森島守人『陰謀・暗殺・軍刀：一外交官の回想』(岩波書店, 1950), p.117.

2 中薗英助『スパイの世界』(岩波書店, 1992), pp.10-11。

3 同注 2, p.7.

4 中西輝政・小谷賢『インテリジェンスの20世紀：情報史から見た国際政治』(千倉書房, 2012), p.25.
} 
大使館や領事館に派遣される駐在武官によって行われる。日本から派遣された武官 は通常、カウンターパートである外国の武官と軍関係者などと情報交換を行い、さ らに新聞などの公開情報などによって情報を集める。また必要な時には現地の人間 を雇い、エージェントとしてグレーゾーンの情報収集活動も指揮する

つまり、日中戦争中の各国の間の情報戦とは、情報を収集する「人」の戦争でもあった のだ。無論、当時の「満洲」では世界各国からの諜者(スパイ)の角逐が絶えず、複雑で

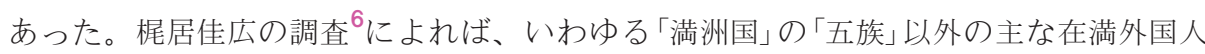
としては、イギリス人、アメリカ人、フランス人、ドイツ人、イタリア人、オランダ 人、ソ連人、白系ロシア人、ポーランド人がいた。その中で、ソ連、アメリカ、イギ リス、フランスの勢力が角逐し合い、多くのスパイも隠れていた。

各国の間のスパイ戦は「満洲」在住の文学者に注目されたことによって、一時的に文学 創作の新しい題材になった。この背景の下でスパイに関する文芸作品も現れ、スパイと いう神秘的な職業は、まず大衆の想像と探究心を引き起こした。各国のスパイに関する 様々な伝説が大衆の間に浸透すると同時に、当時の雑誌と新聞とは大衆の好みに応じて スパイ小説や戯曲・映画の脚本などの通俗文学作品を多く掲載した。『満蒙』に掲載され たスパイに関する作品は「間諜茉莉」の他に、聖田武彦の「スパイと愛欲」、是枝道太の「 新京悲歌」、大庭武年の「峰火」なども挙げられる。これらの作品にはそれぞれスパイが 登場する。

スパイ小説は探偵小説から発展してきたものであるといえよう。「満洲国」が成立し た後、民衆の間では娛楽的、刺激的で新鮮な小説が求められていた。探偵小説はこの大 衆の要求に迎合する産物であると満洲文学研究者の詹麗は指摘している7 新聞は読者の好みに応じて多くの探偵小説を揭載した。それと共に多くの探偵小説家も 現れた。その中で最も有名なのは、在満日本人の大庭武年である。彼の創作した「小盗 児市場の殺人」(雑誌『新青年』、1933年6月)は、「満洲国」時代の最も代表的な探偵小説の 一つであると認められている。

探偵小説の出現には、「満洲」の都市文化の発展と小説家の満洲体験とが深く関わって いる。この点については、植民地文学研究者の柴紅梅が次のように指摘している。

日本の現代主義詩歌が日本本土ではなく日本の植民地都市大連に起源があったよ うに、「日本の探偵小説と植民地都市大連との関係」を考える際にも、人久にしばし ば無視されていた重要な問題が浮かんでくる。すなわち、二十世紀において日本文 壇に活躍していた探偵小説家の相当数が海外の植民地体験を持っており、その多く は中国の東北地方に住んだことがあり、特に都市大連と深い関係があるということ

5 小谷賢(2007)『日本軍のインテリジェンス：なぜ情報が活かされないのか』, 講談社, pp.41-42.

6 梶居佳広(2003)「イギリスからみた日本の満洲支配(1)一戦間期外交報告(Annual Report)を中心に一」、立 命館法学』第290号参考。

7 詹麗 (2017) 『偽満洲国通俗小説研究』, 北方文芸出版社, p.156. 
である。

[筆者訳］

柴紅梅の論述によれば、日本の探偵小説、特に「満洲国」時期における在満日本人の探 偵小説の創作は、日本人の海外の植民地体験と深い関係がある。探偵小説が発展するに つれて、時局を直接に反映したスパイ小説が登場してきたのである。

これまで「満洲国」のスパイ小説に関する系統的な研究は現われていないが、満洲文 学研究者の劉暁麗は、著作の『異態時空中的精神世界——偽満洲国文学研究』で多少ながら 言及している。その調査によると、スパイ小説はその作品の数から言っても作家の数か ら言っても、ほかの通俗文体の作品とは比べられないほど非常に少ない8。劉暁麗は作 家・阿唐のスパイ小説『古廟月夜』(雑誌『麒麟』、1942年2月)を例にして満洲国時期のスパ イ小説を論じ、次のように述べている。

『古廟月夜』は、ある世俗的なストーリ一を語っている。一つの幸福な家庭であっ たが父が殺され、親孝行な娘が父親のために復售する。作者はこの世俗的なスト一 リーをスパイ小説の枠組に置いただけである。物語は満洲国北部のある小さな都市 で発生するが、そこには日・満・露の各国の人々が住んでいる。(略)機密文書を帯び た軍部参謀長である父がスパイに暗殺され、文書も盗まれたが、愛国的な娘が踊子 に変装して敵の内部に入り、兵器を盗もうとする外国の敵対組織を一挙に殲滅し た。作中ではその外国の敵対組織がソ連共産党であることが暗示されている。この 設定は、ある世俗的なストーリーをスパイ小説に変えた ${ }^{9}$ 。[筆者訳]

この指摘の通り、阿唐の『古廟月夜』は、物語の結構からすればすぐれたスパイ小説 とはいえない。作者の阿唐は探偵小説家ではなく、スパイ小説を書く能力を持っていな かったのである。彼はただ当時の時局と大衆の好みに応じてスパイという題材を借り、 「世俗的なストーリー」を書いただけである。この状況からも、当時のスパイという話 題に対する熱量が窺える。

阿唐は日本人ではない。劉暁麗の論述では、在満日本人の書いたスパイ小説には言及 されていない。筆者の知る限りでは、未だ在満日本人のスパイ小説の創作に関する研究 は空白である。しかし、研究の空白は在満日本人の書いたスパイ小説が全くないことを 意味してはいない。

『満蒙』に掲載された在満日本人の書いた通俗小説や戯曲・映画の脚本などをひもとい てみると、スパイを描写する作品が少なくない。第147号に掲載された聖田武彦の「スパ イと愛欲」は、日本とロシアとのスパイ戦を描いたものである。その他、是枝道太の戯 曲脚本「新京悲歌」(第153号)、大庭武年の戯曲脚本「峰火」(第155号)、近東綺十郎の小説

8 劉暁麗『異態時空中的精神世界：偽満洲国文学研究』(華東師範大学出版社, 2008), p.148.

9 同注8, p.151. 
「間諜莱莉」(第164号)などの作品には、スパイの姿が現れている。「新京悲歌」と「峰火」 では「満洲国建国」を破壊するつもりであったスパイが登場した。「間諜茉莉」でも「満洲 国建国」をめぐる日本と各国とのスパイ戦が描かれている。これらの作品を通して在満 日本人の創作したスパイ小説の特徵が窥えるのであろう。

\section{3 時局と接するスパイ小説の創作背景}

前述の聖田武彦の「スパイと愛欲」は『満蒙』における最も早い、スパイに関する小説 である。この小説は主人公のベチロフ、エレナ、ソコロワを巡る物語であり、物語は 「満洲国」の都市・ハルビンという空間で展開され、三人の主人公がスパイ(エレナとソ コロワはロシア人である。大道絵描きとして登場したべチロフが日本人のスパイであ ると疑われている)として設定されている。しかし、この小説は恋愛物語の通俗小説に 留まると考えられる。作者の聖田武彦も、小説の最後に次のように述べている。

読者よ。僕がこれだけで、筆を擱からとすれば、まだ、事件は終わつてるな い。とおつしやる方があるかと思ふ。ベチロフ・ベトロウイチが、日本人のスパイ であつたか、どうか、これは、未知数だからだ。しかし、僕は、恋の殉教者であつ たこの男を、そのま〉、そつとしておいてやりたい。(175頁)

聖田の「僕がこれだけで、筆を擱かうとすれば、まだ、事件は終わつてみない」とい う記述によれば、「スパイと愛欲」の中では、スパイという題材こそ現れたものの、事 件の一部始終を語る敩密な構造を持っていなかったことになる。ただ、スパイという題 材を用いて一つの恋愛物語を描いただけなのである。しかし、ロシア人のスパイとい う設定を通じて当時の日露の間のスパイ戦の様子を示していることは評価すべきところ である。日露戦争の頃から日本とソ連の間には情報戦が続いており、「満洲国」にはソ連 のスパイが特に多かったのである。海野弘は『スパイの世界史』の中で、次のように述 ベている。

1930年代に新たに最も強大なスパイ帝国を作り上げたのはソヴィエト・ロシア連 邦であった。スターリンの全体主義的体制の下に、強力なスパイ網を敷き、国内で は肃清の嵐を巻き起こし、国外には、ひそかにスパイの種をまいていった。ソ連が すぐれていたのはヒューマン・インテリジェンス(人間的スパイ活動)の面において だといわれる ${ }^{10}$ 。

当時の「満洲国」におけるスパイ小説を生み出したのは「満洲」の時局であるといえ

10 海野弘『スパイ世界史』(文芸春秋, 2003), p.146。 
る。スパイ小説は、往々にしてある時期あるいはある事件を暗示するものだからであ る。「間諜莱莉」は、「塘沽停戦協定」を背景にして創作されたもので、「紫茉莉」という偽 名で外国人の社交場ウクライナというダンスホールの踊り子に扮した「一人の孤独なる 少女 ${ }^{11}$ スパイ・日向摩耶子を主人公とした物語である。ここで、まず作者の近東綺十郎 を説明しておきたい。

筆者の調査によれば、近東綺十郎はペンネームであり、その本名は栈朝男である。 北村謙次郎は『北邊慕情記：長篇随筆』の中で「彼は満州文学草わけの一人として早く昭和 五、六年ごろ大連で出た「大陸文学」「街」などの詩や小説を書き「線」これは「作文」の前身 と目される)の青木実や竹内正一などと並んで将来の活躍を予想させていた」 ${ }^{12}$ と近東を 高く評価している。近東の書いた詩は、詩篇「遼河の春」 ${ }^{13}$ (『大陸文学』、1931年6月号) と 「胡秋信」(『我克』、第19号)が代表作として挙げられ、小説は、雑誌『満蒙』で発表した「女 学生陳青娥の更正」(1932年3月)と「間諜茉莉」以外では、雑誌『街』に載せた「雨と肉体と」 (1931年2月号) と『満洲文芸年誌』(1932年3月)に収録された「北満平康里の女」が見つかっ ている。また、近東は詩と小説を創作するだけでなく、大連における戯曲運動にも参加 し、その後、奉天、ハルビン、北京に転居し、新聞記者になったこともある。

大内隆雄は、彼の小説「雨と肉体と」に対して、「近東の「雨と肉体と」は、いかにも彼 らしい表題であるが、内容は当時の風潮を反映してかなりに傾向的なものであつた」 ${ }^{14}$ と評価している。ここから、近東は、「当時の風潮」、或いは時局に非常な興味を持って いたことがわかる。「間諜茉莉」に触れた「塘沽停戦協定」とは1933年5月に、いわゆる「柳 条湖事件」より始まった「満洲事変」の軍事的な衝突をめぐって中国の塘沽において中日両 国の間に締結された軍事的停戦協定である。「間諜茉莉」ではこの事件を示す次の一節が ある。

七月一日、D市の新聞埠頭係りの記者たちは、Tから入港したW丸乗客中に、異様 な一行を発見した。一行は上陸を待ち兼ねた様に、自動車に飛びのつて、そそくさ と、遼河ホテルに、投げ込んでしまつたが、之によつて、北支停戦協定に関しての 細目を決定する大連会議が開かれるといふことは判明した。支那側委員一行、海路来 連のニュースが発表されたのは、その日の夕刊新聞にであつた。(略)

(一)R地方義勇救国軍雑軍の整理に関する問題

$($ 二 $) \times \times 、 \times \times$ 両鉄道の直通運行に関する軍事交涉

(三) $\times \times$ 鉄道の $\times \times$ 鉄道委任経営に関する予備的交渉 ${ }^{15}$

この一節で明確に書かれた「北支停戦協定」とは、塘活停戦協定のことである。ま

11 近東綺十郎「間諜莱莉」(『満蒙』第164号, 1933.12), pp.171-189.

12 北村謙次郎『北邊慕情記：長篇随筆』(大学書房, 1960), p.58.

13 詩篇「遼河の春」は、北村謙次郎の『北邊慕情記：長篇随筆』, p.58に収録されている。

14 大内隆雄『満洲文学二十年』(国民画報社, 1944), p.161.

15 同注 11, p.181. 
た、その日の夕刊新聞が発表したニュースに出てきた「大連会議」の内容には「R」という 頭文字と「メ」の伏せ字で隠されたところがあるが、「R地方義勇救国軍雑軍の整理」とい う表現と「鉄道」の経営に関わる記述がこの事件がなんであるのかをはっきりと示してい る。「義勇救国軍」は東北抗日義勇軍のことであり、これは1931年の満州事変以降、中国 東北部の平民や警察や東北軍の一部の官兵によって構成された義勇軍、救国軍、自衛隊 などの抗日武装組織である。また、R地方は遼河地方である。「雑軍」とは、中核となる 軍事委員会委員長蒋介石直系軍をいわゆる中央軍とし、それ以外の旧東北軍(張学良麾 下)、旧西北軍(馮玉祥麾下)、山西軍(閻錫山麾下)、広西軍(李宗仁、白崇禧麾下)、広東軍 (陳済棠麾下)、四川軍、湖南軍、山東軍、その他の軍から成るものである。

また、小説「間諜茉莉」は「映画風」の叙述方法を採用している。映画風小説、あるいは 映画小説について、大塚英志は映画小説が「従来の「小説」ではなく、「映画」として撮ら れるために「小説」としてある」 ${ }^{16}$ と述べている。「満洲国」が成立した後に、「建国」を宣 伝するために大衆に親しまれる映画と戯曲の製作が在満日本人に工夫され、当時の新聞 と雑誌には映画風小説や戯曲脚本が数多く掲載されていた。映画風小説の特徵は、小説 がいくつかのシーンの描写によって構成されていることである。この特徵は小説の内 容を最も直観的に表わし読者に容易に理解させるため、「建国」を宣伝するのに映画風小 説が有効な手段として利用されていた。これこそが映画風小説が当時に流行っていた原 因なのではないかと思われる。

「間諜茉莉」は、主として以下に示すように十四のシーンから構成され、停戦協定の 一部始終を貫いている。この十四のシーンは小説の構成を示している一方、1933年の 「停戦協定」の政治的な背景も反映している。興味深いことに、物語は「奉天へ走ってい く汽車」(あるいは鉄道)から始まっている。そこだけではなく、「満洲人の車掌」、「満鉄 派遣の日本人車掌監督」「二人の武装した鉄路警備員」、「山海関駅」「白廟子駅」「「興 城駅、特急「はと」などの鉄道に関連した人や物の存在が次々に登場する。

どうして鉄道が物語の展開の道具として使用されるのかという問いに答えるために は、小説創作における社会背景への想像が必要である。つまり、「満洲事変」の軍事的な 衝突と深くかかわる「柳条湖事件」である。周知のように、「柳条湖事件」は日本関東軍の 謀略によって起こった、満洲事変の発端となる鉄道爆破事件であった。鉄道から始まる というのは、「塘沽停戦協定」の締結の起点としての「柳条湖事件」を容易に連想させる。 この事件によって、「汽車」、あるいは鉄道という存在が政治的にも社会的にも話題に なっていた。また、締結された「停戦協定」の中で「鉄道」問題が重要な議題として取り扱 われていたことも鉄道が重要な道具立てとなった一つの原因だと考えられる。

16 大塚英志「サブカルチャ一/文学論 中上健次とエイゼンシュテインの「映画小説」」(『小説tripper：トリッ パー』, 2007), pp.338-348. 


\section{4 帝国主義による「茉莉」の英雄物語}

「五族協和」が「満洲国」の建国理念として日本に標榜されるとともに、文学作品におい ても一部の作家が「五族協和」という理念を作品に取り入れた。それらの作中では主人公 がしばしば英雄として描かれている。「間諜茉莉」のなかの茉莉の人物像については、一 つは「英雄」であるといえる。このような人物叙述は、帝国主義の立場に立っていると考 えられる。

作者がいかにして茉莉を英雄のように語っていたかについて、まず、茉莉の生い立 ちから見ていく。そこでは茉莉となる前の「摩耶子」の家庭環境が非常に興味深いもので ある。摩耶子の父親は、「今を去る約二十年前以来、満洲義軍の先頭として、又沿海洲独 立運動の中堅となつて活動した、彼の日向直樹老先生」17なのであり、母親の「淑媛と言 ふのは清朝没落の当時の老臣 $\mathrm{K} の$ 令妹で、若い日の日向直樹との交情から、その正夫人

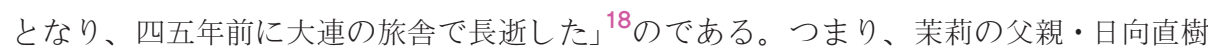
は日本人で、母親・淑媛は満洲人(中国人)である。

このような設定は「五族協和」が揭げられた時代背景と関わっているに違いない。父 親が大和民族 (日本人)であり、母親が満洲人(母淑媛太太は清朝没落当時の老臣の妹で あった。また、大連の旅社で逝去したということは、「満洲」で生涯を過ごした可能性が ある。これらの描写より、「満洲人」だと推測できる)であったことは、日満の「協和」を 宣伝しているといえよう。

それだけでなく、父親が日本人で母親が満洲人であったという設定自体にも深い意 味がある。「父権」が支配的な地位を相変わらず占めていた社会においては、茉莉の父親 は単に父親であるだけではなく、日本民族の支配的な地位をも代表しているはずであ る。一言で言えば、日本人であるからこそ父親になり、満洲人であるからこそ母親に なったのである。日本が「五族協和」を建国の理念として、大和族・満洲族・漢族・モン ゴル族・朝鮮族の五つの民族を協調して暮らせる「国」を主張する一方で、現実には大和 族(日本民族)が支配的な地位を占めることは、やはり無視することはできない。以上の ことから、「五族協和」の理念を宣伝するという点からみて「間諜茉莉」はまず、帝国主義 を反映した作品であるといえる。

両親の身分についての設定という側面だけではなく、「紫茉莉」という名前を持つ主 人公のスパイとしての短い生涯に対する描写も、この傾向をはっきりと表している。茉 莉が所属していた組織・「大同亜細亜青年同盟」は日本の情報組織として存在し、「五族協 和」の理念を積極的に提唱している様子が見られる。この組織の役目は、日本のために 「満洲」における各国の勢力のさまざまな情報を探ることであった。この組織に属する茉 莉は、日本が「満洲国」を「建設」する一助となった。そのため、「建国」に尽力する莱莉

17 同注 11, p.173.

18 同注 11, p.177. 
は、間違いなく英雄のように語られている。

茉莉の英雄的なイメージを最も表現しているのは、小説の最後で描かれた莱莉の死 の部分である。そこで茉莉自身が自分の死を「皇国のため……亜細亜のため」 ${ }^{19}$ と認識し て死んでいったことは、茉莉が自分の意思で死」を選ぶことを強調しているものかと思 われる。また作者は、「北平をはなれて僅か三ヶ月一女間諜茉莉は死んだ……一亜細 亜のために一」 ${ }^{20}$ というような帝国主義の慣例的な言葉で、物語に終止符を打ってい る。言うまでもなく、茉莉の死に直面した際の最後の言葉にしても、作者からの茉莉の 死に対する語り方にしても、すべて英雄型の語り方であると思われる。作者が間諜茉莉 の死を「英雄の犠牲」としたのは、日本帝国主義の最高のスローガンになったのではない かと考えられる。

一方、別の側面からみれば、莱莉の死という悲劇的な結末は、英雄物語でありつつ も、犠牲者であるというスパイ戦に対する内部的批判を僅かではあるが表している。

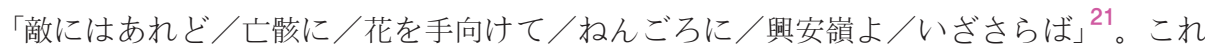
は小説の最後で莱莉の死を記念するために、作者が捧げた歌である。

この歌は、八木沼丈夫 ${ }^{22}$ が創作した軍歌「討匪行」の終わりの部分であり、関東軍参謀 部によって選定・発表された、「満洲」で中国東北軍を「討伐」する将兵の姿を描いたもの である。「討匪行」は軍制定の純粋な軍歌であるが、厭戦・反戦歌のような歌詞・曲調で 多くの人久に歌われていた。食事も補給もなく愛馬も倒れ、時には空を仰ぎながら涙を 流し、戦友と生きて再会できた喜びに歓喜しながらも黙々と泥濘の道をいく様子や、敵 の死体に花を手向けてकう様子など、前線を実感的に表現している。

作者の近東は、小説の終わりの部分で軍歌『討匪行』を通じて茉莉の死を記念した。こ れはもち万ん、茉莉の「皇国のため」の死を賛美することには違いないが、この歌を詠 むことは戦争のもたらした苦痛を人々に感じさせもするのではないかと考えられる。 つまりこの厭戦・反戦的性質のある軍歌から見れば、「間諜茉莉」には、スパイ戦に対す る内部的な批判があるといえるだろう。

茉莉の死を分析する際、「皇国のため」以外のもう一つの要因も無視されてはならな

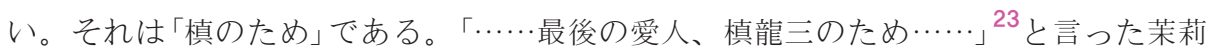
は、槙との恋に落ちた。しかしながら、この切ない恋愛は帝国主義の下では実現できな いものであった。「一片の茶毘の煙と化した」24茉莉の死体も、「寂しい」槙の心も、すべ

19 同注 $11, \mathrm{p} .189$.

20 同注 11, p.189.

21 同注 11, p.189.

22 日本の陸軍軍属、歌人。日中戦争(支那事変)において日本軍が本格的に宣掹官を導入するきっかけとなっ た人物。1917年(大正6年)には中国大陸へ渡り、1919年(大正8年)に現地で結婚。1929年(昭和4年)、南満洲 鉄道に入社し、その後関東軍に配属される。抗日ゲリラ掃射に従事する討伐隊をうたった軍歌「討匪行(と うひこう)」を作詞(関東軍参謀部嘱託)、作曲および創唱歌手は戦前日本を代表するオぺラ歌手であった藤 原義江。「討匪行」は1942年(昭和17年)12月に、ビクターレコードより発売されている。

23 同注 11, p.189. 
て帝国主義という背景の下では恋愛が不可能であるという証拠になったのである。つま り、スパイ戦は恋愛の障害物になるといえよう。スパイの茉莉もその犠牲者になったの である。犠牲というのは、主に以下の三点にまとめられる。

\section{1 身分の堕落：名媛から踊り子(スパイ)へ}

莱莉とチャップマンとの間のスパイ戦を見ていこう。チャップマンは、1933年の 「停戦協定」が行われた時期のユーナイデッド・コーレスポンデンス満洲特派員であると 同時に「某国」に派遣された一人のスパイであるという設定である。彼の目的は「停戦協 定」の情報を效取することであった。彼は「大同亜細亜青年同盟」に「反満洲国的仕事を為 しつつある」 ${ }^{25}$ と疑われていた。一方、茉莉は、「大同亜細亜青年同盟」のスパイで、「茉 莉」という名前で、外国人の社交場ウクライナというダンスホールの踊り子に変装して いた。彼女の任務はチャップマンを操縦することである。

「停戦協定」をめぐる会議の進展とともに、茉莉とチャップマンの物語は進んでいっ た。二人の関係は「協定」会議の開始とともに開始され、会議の終焉とともに終焉を迎え たといえよう。前にも述べたように、茉莉はスパイになる前に、自分の美しさに惹か れたチャップマンと汽車で出会っている。「大同亜細亜青年同盟」にってスパイになっ た後の茉莉は踊り子という身分でチャップマンと偶然に再会したチャンスを活かし、 チャップマンの日常生活に順調に介入していった。

チャップマンは莱莉に会うため毎晚ウクライナにやってきた。二人の関係はますま す密接になっていった。そのなかで、情欲に駆られて興奮したチャップマンが一度茉莉 に対して性的侵犯をしようとしたことがあったが、茉莉に逃げられた。そのため、茉 莉のチャップマンに対する監視は中断された。しかし、スパイの仕事を続けるため に、茉莉は特急「はと」の展望車にて、チャップマンと偶然を装って会う場面を再び作り 出し、二人の誤解が解けたように見せかけた後で、彼の住んでいる場所を知り監視を続 行できるようになった。その後、「停戦協定」の資料を窃取にいったチャップマンの姿は 一時的に消えてしまうが、やがて戻ってくる。彼は莱莉を連れて逃げようと思ったが、 槙龍三に追いかけられる。その過程で、茉莉は自分のスパイという身分を告白し死んで しまう。

こうしてみると、莱莉とチャップマンはスパイ戦によって作り上げられた関係であ るといってもよいだろう。この関係から莱莉を分析すると、彼女は悲しく虚しい存在で あったと結論づけられる。なぜならば、まず「名媛」といら身分から「スパイ」の踊り子 にまで堕ちたこと(無論、帝国主義の角度から見れば、英雄主義の表現である) は不幸の 開始であると考えられるためだ。彼女がスパイになる前は、独立した生活を持つ知的な

24 同注11, p.189.

25 同注11, p.177. 
女性というイメージを人々に与えるが、スパイに転じてからはそれは残酷なスパイ戦 の鋭い武器になった。スパイ戦を批判する角度から見ると、これは身分の随落だといえ るだろう。

何の感情もなく、ただ情報を窃取するという役目のためだけに生きている茉莉は虚 しい存在でもあった。無論、莱莉の美貌に惹かれていつも情欲に目を輝かせていた チャップマンが、内心茉莉にどのぐらい気持ちがあったのかについては何もいえな い。それはともかく、莱莉にとってこの関係は本心ではなく、チャップマンとの交渉 もいわば、本心に逆らう行動であった（帝国主義によって「皇国のため」を標榜しはした が)。冷たいスパイ戦に巻き込まれた莱莉は結局、死め運命から逃れられなかった。死 ぬ前の「……皇国のため……亜細亜のため……最後の愛人、槙龍三のため……という言 葉は逆に読者に何も言えない虚しさを感じさせる。むしろ帝国主義を抜きにすれば、無 意義の犠牲であるといえるだろう。

\section{2 失敗した茉莉の恋}

一方、小説の中の茉莉と槙との恋は結ばれなかった。むしろ、始まらなかったとも いえよう。なぜかというと、（槙からも莱莉からも）直接に明確な告白がなかったからで ある。莱莉は奉天に来て以降、槙のことが好きであるということが文脈から窺えるが、 直接の告白はなかった。彼女はチャップマンの行方が分からなくなった事件で槙に電話 をした時に、「あのう、……会議がすんだら、一日位一緒に、ここのホテルで愉快に遊 べないかしら」 ${ }^{26}$ と話した。これが茉莉の槙への「告白」のようなものであったが、槙か らの「誰と、チャップマンと？……」 ${ }^{27}$ といら返事をみ机ば、彼女の気持ちは届かな かったようである。茉莉の愛に対して、槙は何かを感じたかも知机ないが、それには 答えられないほど微かなものであった。

これはおそらく、槙の人物像とかかわっているだろう。小説に槙の性格についての 直接的な描写はほとんど見られないが、文脈をよく整理すると、槙龍三の性格、あるい は人物像を少しずつ明らかにすることができる。前にも述べたように、槙龍三は莱莉が わざわざ北平から奉天にやって来て会う対象である。彼は「大同亜細亜青年同盟」に所属 している人物で、茉莉やチャップマンと比べると、作者の彼に対する描写はあまり多い とは言えない。槙の外貌は彼の仲間の口から語られており、「色男」、「美男子」と呼ば れ、「娘の子に騒がれそうな顔」だとされる。詳しく数えると、槙龍三の小説内での主な 登場はただ五回だけである。茉莉と初めて会ったときと、茉莉の葬式に出たときの二回 を除けば、残る三回のうち二回は、チャップマンと茉莉の様子を監視していたときで、 もう一回はチャップマンの行方が分からなくなったため、莱莉が槙に電話したときで

26 同注 $11, \mathrm{p} .182$.

27 同注 11, p. 183 . 
あった。以上の設定からみると、槙の任務は茉莉とチャップマンの様子を監視して必要 な行動を取ることであった。

さらに文脈を整理すると、槙の性格の中には主に三つの特徵がある。まずは、彼の 言動から示された「慎重」かつ冷たい性格である。茉莉がチャップマンに性的に侵犯され る事件の中で、槙のそのような性格が見られる。逃げた茉莉が事件の経過を打ち明けた 後、槙は「……今晚は充分に臥んで下さい。我々の仕事が成功するまでは、まだまだ倒 れてはいけない身体ですからねえ…… 28 という言葉を口にした。慎重で安心させる言 葉だったが、どこか仕事がまだあるので死んではいけないという冷たい印象がこの場 面から伝わってくる。

次は彼の「満洲国」への擁護である。槙にしても、仲間の酒井にしても、また死んだ 茉莉の父親日向直樹にしても、彼らはすべて「満洲開拓団」に伴って満洲にきていた。 1932年に「満洲国」が樹立されたと同時に、槙のような日本人は「満洲国人」になった。槙 が所属した「大同亜細亜青年同盟」は一切の「反満洲国」の行為と戦う組織であった。槙の 眼には「支那人」、「露西亚人」という民族区分が確かに映されている。槙がはじめて茉莉 に会った時に、彼は茉莉を「支那人」と見間違った。それに、監視任務の中で露西亜人」 の踊り子に目を注いだことも同じく、彼が日本人以外の存在に関心を持っていたことを 明らかにしている。つまり、槙は「満洲国』の「五族協和」といった理念を認識していて 「満洲国」を擁護していたのである。また、槙も帝国主義への絶対的な服従者であった。 「彼等のみ栄えんがため滅びゆく／亜細亜、亜細亜、我等が亜細带」 ${ }^{29}$ 。これは槙の歌で あった。

要するに、槙は、帝国主義に駆られた在満日本人のイメージを持っているのであ る。こういう背景の下で、槙は帝国主義に描かれた傆気楼に心酔し、茉莉の愛を完全に 無視した。帝国主義の暗闇で、茉莉と槙との恋愛には光が決して差し込まない。このよ うに考えると、茉莉の愛はやはり虚しかったのである。

\section{3 茉莉の死：帝国主義の犠牲者}

茉莉は愛人槙の懷中で死ぬことができなかったどころか、その死体はチャップマン によって路上に遺棄された。翌日、彼女の死体は火葬場に運ばれ、一片の茶毘の煙と化 した。茉莉の死はこの物語に終止符を打つと同時に長い感傷を残した。読者はこの悲し みに包まれているらちにいつの間にか、何も悪いことをしていない茉莉がどうして死 ななければいけないのかという問いを抱くようになるだろう。茉莉の死については、 以下の二点が非常に興味深い。

一つは茉莉が槙の弾丸に撃たれたことであった。茉莉は最初に自分の思いを寄せた

28 同注 11, p.179.

29 同注 11, p.181. 
愛人槙の弾丸に撃たれて倒れたのである。ここには、どうしてそのような設定がある のかという疑問が生じるが、「愛」と「任務」との間にその答えは見つかるかも知れな い。つまり、「愛」と「任務」のどちらが優先されたかを考えれば、明らかに任務が勝利し たのである。追いかけたチャップマンの自動車に茉莉がいるにもかかわらず、槙は自 分の任務を果たすためにピストルを撃った。言い換えれば、茉莉の安全は無視されたの である。

それに対して、茉莉は間諜としての任務を完遂させるため自分が愛する人の弾丸に 撃たれたことには、何の文句もなかった。変わらず槙のことを思いながら、黒い力バ ンを車体の外に投げるという任務を完遂したあと、死に直面した。槙が莱莉のことを好 きかどうかは小説の中にははっきりとは書かれていなかった。しかし、槙は「茉莉は自 分をあいしてくれているのではなかららか」 ${ }^{30}$ と考えたことがある。この自問からみれ ば、槙は内心では茉莉のことを愛していたのかもしれない。だが、茉莉の葬式に出た槙 の目には涙がなかった。理由を考えると、やはり「任務」を完遂したからだろう。

もう一つは、いわゆる「何等の被害」も加えられていなかったことである。茉莉が死 んだあと、「凱歌を挙げた。天佑的に、何等の被害も、未だくわえられていなかったの だ」 ${ }^{31}$ と作者はこのような言葉を使った。茉莉の死の悲しさと凱歌とは明らかに対照的 である。帝国主義を代表していた捜索隊は少しも茉莉の死を悲しく感じていなかっただ ろう。ここでは、「凱歌」という言葉が使用され、人間性を潰す帝国主義の本質が側面か ら照射される。ここでようやく、前に出てきた何も悪いことをしていない茉莉がどう して死ななけ杖いけないのか」という問いに答えられるだろう。要するに、帝国主義 は、スパイになった茉莉を助けるはずはなかったのである。いわば、最後に茉莉は帝 国主義の犠牲者になったのである。

\section{5 おわりに}

「満洲国」成立後、「満洲」では各国間の勢力が互いに角逐し、スパイ戦が激しくなっ た。こうした社会背景の下で、スパイを描く文学作品が現われてきた。その一例として の「間諜茉莉」は、在満の日本女間諜を描いた小説である。その中で登場した日本人の女 スパイ・茉莉、外国間諜のチャップマン、露西亜の踊り子などの、彼らのような存在は 「満洲国」には確かに存在した。スパイ小説の出現は当時の都市発展による都市文化の成 熟及び探偵小説などの通俗文学の流行と関係があると思われる。また、各国間の勢力の 角逐という複雑な社会背景は、スパイ小説の創作に基礎的な素材を提供したといえよ う。

30 同注11, p.181.

31 同注 11, p.189. 
時局と接するのは、スパイ小説の最も大きな特徴であると言えよう。「間諜莱莉」は 「塘沽停戦協定」を背景にして創作されたものである。また、小説における英雄型の物語 の創作は、「愛国」精神を表し、日本帝国主義を擁護する傾向も示している。それと共 に、戦争による人々の死亡や、災難や、悲惨な運命などもその内部には反映されてい る。スパイ戦で死んだ茉莉はその一例である。スパイ戦に巻き込まれた茉莉は、表向き は英雄として描かれる一方で、その裏ではスパイ戦の犠牲者としても描かれている。

植民地空間で創作された文学の多くは、植民地支配者の意思に配慮し、支配者の立場 や視野から見て許される架空の風景を描いただけである。それに対して、もっと客観的 な、実際の生活の様態については隠されていたのである。無論、小説「間諜茉莉」は「五 族協和」の理念を唱えた帝国主義を表す文学作品として、以上に述べた植民地文学の性 格、あるいは本質から逃れられなかった。

\section{参考文献}

森島守人 (1950)『陰謀・暗殺·軍刀：一外交官の回想』，岩波書店. Morishima. Morito (1950) Plot, assassination, saber : a diplomat recalls Iwanamisyotenn..

中薗英助(1992)『スパイの世界』, 岩波書店. Nakazono, Eisuke(1992) The world of spies I wanamisyotenn. 中西輝政・小谷賢 (2012)『インテリジェンスの20世紀：情報史から見た国際政治』, 千倉書房. Nakanisi, Terumasa - Kotani. Kenn(2012) The 20th century of intelligence: international politics in the history of intelligence Chikurasyobou.

小谷賢 (2007)『日本軍のインテリジェンス：なぜ情報が活かされないのか』、講談社. Kotani, Kenn (2007) Japanese intelligence: why is intelligence not used? Koudannsya.

梶居佳広 (2003)「イギリスからみた日本の満洲支配 (1)一戦間期外交報告 (Annual Report)を中心に一」、立命館 法学」第290号. Kajii. Yosihiro (2003) Japanese domination of manchuria from Britain (1)：Annual Report on interwar diplomacy Ritsumeikanhougaku(290).

詹麗 (2017) 『偽満洲国通俗小説研究』, 北方文芸出版社. Zhanli (2017) Study on popular novels of manchukuo North literature and art publishing.

劉暁麗 (2008) 『異態時空中的精神世界：偽満洲国文学研究』、華東師範大学出版社. Liuxiaoli (2008) Spiritual world in the air at different times : a study of manchukuo literature East China normal university press.

海野弘 (2003)『スパイ世界史』, 文芸春秋. Umino. Hiroshi (2003) World history of spies KabusikigaisyaBunngeisyunnsyuu.

近東綺十郎(1933)「間諜莱莉」『満蒙』, 第164号, pp.171-189. Konntou, Kijirou(1933) Spy Molly Mannmou(164), pp.171-189.

北村謙次郎 (1960) 『北邊慕情記：長篇随筆』。大学書房. kitamura, Kennijrou(1960) North affection note : long essay Daigakusyobou.

大内隆雄(1944) 『満洲文学二十年。, 国民画報社. Oouchi. Takao(1944) Twenty years of manchurian literature Kokuminngahousya.

大塚英志 (2007)「サブカルチャー/文学論 中上健次とエイゼンシュテインの「映画小説」」、『説tripper：ト リッパー』. pp.338-348. Ooduka. Eiji(2007) Subculture/literary theory : the Film novel of Nakaue kennji and Aisenstein Novel tripper. pp.338-348. 